\title{
Pengendalian Persediaan Bahan Baku pada PT. Aceh Rubber Industries Kabupaten Aceh Tamiang
}

\author{
Dewi Rosa Indah ${ }^{1 *)}$, Linda Purwasih ${ }^{2)}$, Zenitha Maulida ${ }^{3)}$ \\ ${ }^{1,2)}$ Fakultas Ekonomi, Program Studi Manajemen, Universitas Samudra \\ ${ }^{3)}$ Sekolah Tinggi Ilmu Ekonomi Sabang (STIES) Banda Aceh \\ e-mail: dewirosaindah@unsam.ac.id, zenitha.abadi@gmail.com
}

\begin{abstract}
Abstrak
Penelitian ini bertujuan untuk mengetahui pengendalian persediaan bahan baku yang dilakukan oleh PT. Aceh Rubber Industries Kabupaten Aceh Tamiang. Data yang digunakan dalam penelitian ini adalah data sekunder yang bersumber dari catatan perusahaan selama satu tahun (Januari - Desember 2016). Metode analisis data yang digunakan dalam penelitian ini yaitu metode Economic Order Quantity (EOQ), yang bertujuan untuk mengetahui pemesanan paling paling ekonomis, Total Inventory Cost (TIC), Safety Stock (SS), dan Re Order Point (ROP). Hasil penelitian yang diperoleh adalah pembelian bahan baku yang optimal menurut kebijakan perusahaan yaitu sebesar $113.631 \mathrm{~kg}$ dengan frekuensi pemesanan sebanyak 48 kali dalam satu tahun, sedangkan berdasarkan metode EOQ yaitu sebesar $346.588 \mathrm{~kg}$ dengan frekuensi pemesanan sebanyak $16 \mathrm{kali}$ dalam satu tahun. Total biaya persediaan menurut kebijakan perusahaan adalah sebesar Rp 4.097.678, sedangkan berdasarkan metode EOQ sebesar Rp 2.426.466. Persediaan pengaman (Safety Stock) menurut kebijakan perusahaan tidak ada, sedangkan menurut metode EOQ adalah sebesar $200.693 \mathrm{~kg}$. Titik pemesanan ulang (Re Order Point) menurut kebijakan perusahaan tidak ada, sedangkan menurut metode EOQ adalah sebesar $323.067 \mathrm{~kg}$.
\end{abstract}

Kata kunci: Pengendalian persedian, Bahan baku, EOQ

\section{PENDAHULUAN}

Masalah produksi merupakan masalah yang sangat penting bagi perusahaan karena hal tersebut sangat berpengaruh terhadap laba yang diperoleh perusahaan. Apabila proses produksi berjalan dengan lancar maka tujuan perusahaan akan tercapai, akan tetapi apabila proses produksi tidak dapat berjalan dengan lancar maka tujuan perusahaan tidak akan tercapai. Sedangkan kelancaran proses produksi itu sendiri dipengaruhi oleh ada atau tidaknya bahan baku yang akan diolah dalam kegiatan produksi. Bahan baku merupakan salah satu faktor yang penting bagi berlangsungnya suatu proses produksi, tanpa adanya bahan baku maka kegiatan produksi akan terhambat. Karena bahan baku merupakan unsur penting dalam proses produksi, maka persediaan bahan baku tersebut harus diperhatikan. Persediaan bahan baku dimaksudkan untuk memenuhi kebutuhan bahan baku untuk proses produksi pada waktu yang akan datang, sehingga perusahaan akan tetap berpoduksi dan mampu memenuhi kebutuhan konsumen. Dengan adanya persediaan yang optimal perusahaan akan mampu menentukan seberapa besar persediaan bahan baku yang sesuai, sehingga tidak menimbulkan pemborosan biaya karena mampu menyeimbangkan kebutuhan bahan baku yang tidak terlalu banyak maupun persediaan yang tidak terlalu sedikit. 
Adanya persediaan bahan baku yang terlalu besar dibandingkan kebutuhan perusahaan dalam proses produksi, maka akan menambah beban biaya penyimpanan dan pemeliharaan dalam gudang, serta adanya kemungkinan terjadinya penyusutan kualitas yang tidak bisa dipertahankan sehingga perusahaan akan mengalami kerugian. Namun, jika persediaan itu telalu sedikit, mengakibatkan risiko terjadinya kekurangan persediaan (stock out) karena seringkali bahan atau barang tidak dapat didatangkan secara mendadak dan sebesar yang dibutuhkan, yang akan menyebabkan terhentinya proses produksi, tertundanya penjualan, bahkan hilangnya pelanggan.

Oleh karena itu setiap perusahaan khususnya perusahaan industri harus tepat dalam mengendalikan persediaan agar persediaan bahan baku selalu ada dan tidak mengalami kekosongan serta dapat menekan biaya persediaan seminimal mungkin. Salah satu metode manajemen persediaan yang paling terkenal adalah model kuantitas pesanan ekonomis “Economic Order Quantity” (EOQ). Perencanaan dalam metode EOQ pada perusahaan dapat meminimalisasi terjadinya out of stock sehingga tidak mengganggu proses produksi dalam perusahaan dan mampu menghemat biaya persediaan yang dikeluarkan oleh perusahaan tersebut. Selain itu, penerapan metode EOQ pada perusahaan akan mampu mengurangi biaya penyimpanan, penghematan ruang, menyelesaikan masalah yang timbul dari banyaknya persediaan yang menumpuk sehingga mengurangi risiko yang dapat timbul karena persediaan yang ada di gudang.

PT. Aceh Rubber Industries Kabupaten Aceh Tamiang merupakan salah satu perusahaan yang bergerak dibidang industri pengolahan karet mentah alam menjadi karet lembar (rubber sheet). Bahan baku utama yang digunakan dalam proses produksi ini adalah karet mentah alam. Perusahaan ini selalu mengupayakan agar proses produksi tetap berjalan lancar. Dalam kegiatan pengadaan bahan baku PT. Aceh Rubber Industries Kabupaten Aceh Tamiang mempunyai pemasok atau supplier bahan baku karet mentah. Selain itu PT Aceh Rubber Industries juga melakukan sistem pembelian langsung tanpa perantara (tanpa melalui supplier), dimana petani pemilik getah bisa menjual getah yang dipanennya langsung ke pabrik, berapapun jumlah getah yang dibawa petani dibeli dengan harga yang wajar. Oleh karena itu, PT. Aceh Rubber Industries harus selektif dalam memilih supplier agar diperoleh bahan baku yang berkualitas dan harga bahan baku yang sesuai dengan keinginan perusahaan tersebut. Dalam hal ini perusahaan harus tepat dalam merencanakan pembelian bahan baku agar perusahaan dapat mengefisienkan biaya-biaya yang berhubungan dengan persediaan. Selama ini kendala yang dihadapi oleh PT. Aceh Rubber Industries Kabupaten Aceh Tamiang yaitu pasokan bahan baku yang belum lancar, karena para agen getah di Aceh masih menjual getahnya ke daerah lain. Selain itu, para supplier juga terkadang lambat mengirimkan bahan baku karena para petani karet pada saat tertentu tidak dapat menghasilkan getah yang maksimal yang disebabkan oleh faktor alam seperti hujan dan karet mengalami rontok daun, sehingga persediaan bahan baku yang ada di perusahaan kurang optimal dan menyebabkan proses produksi tidak dapat berjalan dengan lancar.

Oleh karena itu, dalam lingkup pengendalian persediaan bahan baku, ketersediaan bahan baku dapat berpengaruh terhadap proses produksi. Sebab baik kelebihan maupun kekurangan persediaan 
akan menimbulkan kerugian dalam perusahaan. Kekurangan persediaan bahan baku akan menyebabkan terhentinya proses produksi, sedangkan kelebihan persediaan akan mengakibatkan timbulnya risiko kerusakan, penurunan nilai, besarnya dana yang harus ditanamkan sehingga dana untuk investasi lain berkurang, kenaikan biaya-biaya penyimpanan dan biaya-biaya lainnya yang berhubungan dengan persediaan akan meningkat. Dengan menerapkan metode EOQ, diharapkan perusahaan dapat menimimalkan biaya-biaya yang dikeluarkan dengan menentukan seberapa besar persediaan bahan baku perusahaan itu sendiri, sehingga dapat menghasilkan laba yang optimal.

\section{TINJAUAN PUSTAKA}

\section{Faktor-faktor Yang Mempengaruhi Persediaan}

Adapun faktor-faktor yang mempengaruhi persediaan bahan baku menurut Ahyari dalam dalam Rasyid (2015) adalah sebagai berikut:

1. Perkiraan bahan baku

Sebelum perusahaan mengadakan pembelian bahan baku, maka selayaknya manajemen perusahaan mengadakan penyusunan perkiraan pemakaian bahan baku untuk keperluan produksi. Hal ini dapat dilakukan dengan mendasarkan pada perencanaan produksi dan jadual produksi yang telah disusun sebelumnya. Jumlah bahan baku yang akan dibeli perusahaan tersebut dapat diperhitungkan, dengan cara jumlah kebutuhan bahan baku untuk proses produksi ditambah dengan rencana persediaan akhir dari bahan baku tersebut, dan kemudian dikurangi dengan persediaan awal dalam perusahaan yang bersangkutan.

2. Harga bahan baku

Harga bahan baku yang digunakan dalam proses produksi merupakan salah satu faktor penentu seberapa besar dana yang harus disediakan oleh perusahaan yang bersangkutan apabila perusahaan tersebut akan menyelenggarakan persediaan bahan baku dalam jumlah unit tertentu. Semakin tinggi harga bahan baku yang digunakan perusahaan tersebut maka untuk mencapai sejumlah persediaan tertentu akan memerlukan dana yang semakin besar pula.

3. Biaya-biaya persediaan

Dalam hubungannya dengan biaya-biaya persediaan ini dikenal tiga macam biaya persediaan yaitu biaya penyimpanan, biaya pemesanan dan biaya tetap persediaan. Biaya penyimpanan merupakan biaya persediaan yang jumlahnya semakin besar apabila jumlah unit bahan yang disimpan didalam perusahaan tersebut semakin tinggi. Biaya pemesanan merupakan biaya persediaan yang jumlahnya semakin besar apabila frekuensi pemesanan bahan baku yang digunakan dalam perusahaan semakin besar. Biaya tetap persediaan merupakan biaya persediaan yang jumlahnya tidak terpengaruhi baik oleh jumlah unit yang disimpan dalam perusahaan ataupun frekuensi pemesanan bahan baku yang dilaksanakan oleh perusahaan tersebut.

4. Kebijakan pembelanjaan

Kebijakan pembelanjaan yang dilaksanakan didalam perusahaan akan berpengaruh 
terhadap penyelenggaraan persediaan bahan baku dalam perusahaan tersebut. Seberapa besar dana yang dapat digunakan untuk investasi didalam persediaan bahan baku tentunya juga tergantung dari kebijakan perusahaan, apakah dana untuk persediaan bahan baku ini dapat memperoleh prioritas pertama, kedua atau justru yang terakhir dalam perusahaan yang bersangkutan. Disamping itu tentunya financial perusahaan secara keseluruhan juga akan mempengaruhi kemampuan perusahaan untuk membiayai seluruh kebutuhan persediaan bahan bakunya.

5. Pemakaian bahan baku

Hubungannya antara perkiraan pemakaian bahan baku dengan pemakaian senyatanya di dalam perusahaan yang bersangkutan untuk keperluan pelaksanaan proses produksi akan lebih baik apabila diadakan analisis secara teratur, sehingga akan dapat diketahui pola penyerapan bahan baku tersebut. Dengan analisis ini dapat diketahui apakah model peramalan yang digunakan sebagai dasar perkiraan pemakaian bahan ini sesuai dengan pemakaian senyatanya atau tidak. Revisi dari model yang digunakan tentunya akan lebih baik dilaksanakan apabila ternyata model peramalan penyerapan bahan baku yang digunakan tersebut tidak sesuai dengan kenyataan yang ada.

6. Waktu tunggu (lead time)

Waktu tunggu merupakan tenggang waktu yang diperlukan antara saat pemesanan bahan baku tersebut dilaksanakaan dengan datangnya bahan baku yang dipesan tersebut. Apabila pemesanan bahan baku yang akan digunakan oleh perusahaan tersebut tidak memperhitungkan waktu tunggu, maka akan terjadi kekurangan bahan baku (walaupun sudah dipesan), karena bahan baku tersebut belum datang ke perusahaan. Namun demikian, apabila perusahaan tersebut diperlukan, maka perusahaan yang bersangkutan tersebut akan mengalami penumpukan bahan baku, dan keadaan ini akan merugikan perusahaan yang bersangkutan.

7. Model pembelian bahan baku

Model pembelian bahan yang digunakan oleh perusahaan sangat berpengaruh terhadap persediaan bahan baku yang dimiliki perusahaan. Model pembelian yang berbeda akan menghasilkan jumlah pembelian optimal yang berbeda pula. Pemilihan model pembelian yang akan digunakan oleh suatu perusahaan akan disesuaikan dengan situasi dan kondisi dari persediaan bahan baku untuk masing-masing perusahaan yang bersangkutan. Karakteristik masing-masing bahan baku yang digunakan dalam perusahaan dapat dijadikan dasar untuk mengadakan pemilihan model pembelian yang sesuai dengan masing-masing bahan baku dalam perusahaan tersebut. Sampai saat ini, model pembelian yang sering digunakan dalam perusahaan adalah model pembelian dengan kuantitas pembelian yang optimal (EOQ).

8. Persediaan pengaman

Persediaan pengaman untuk menanggulangi kehabisan bahan baku dalam perusahaan, maka diadakan persediaan pengaman (safety stock). Persediaan pengaman digunakan perusahaan 
apabila terjadi kekurangan bahan baku, atau keterlambatan datangnya bahan baku yang dibeli oleh perusahaan. Dengan adanya persediaan pengaman maka proses produksi dalam perusahaan akan dapat berjalan tanpa adanya gangguan kehabisan bahan baku, walaupun bahan baku yang dibeli perusahaan tersebut terlambat dari waktu yang diperhitungkan. Persediaan pengaman ini akan diselenggarakan dalam suatu jumlah tertentu, dimana jumlah ini merupakan suatu jumlah tetap didalam suatu periode yang telah ditentukan sebelumnya.

9. Pembelian kembali

Dalam melaksanakan pembelian kembali tentunya manajemen yang bersangkutan akan mempertimbangkan panjangnya waktu tunggu yang diperlukan didalam pembelian bahan baku tersebut. Dengan demikian maka pembelian kembali yang dilaksanakan ini akan mendatangkan bahan baku ke dalam gudang dalam waktu tepat, sehingga tidak akan terjadi kekurangan bahan baku karena keterlambatan kedatangan bahan baku tersebut, atau sebaliknya yaitu kelebihan bahan baku dalam gudang karena bahan baku yang dipesan datang terlalu awal.

\section{Bahan Baku}

Bahan baku adalah bahan yang membentuk bagian menyeluruh produk jadi. Bahan baku yang diolah dalam perusahaan manufaktur dapat diperolah dari pembelian lokal, impor atau dari pengolahan sendiri (Mulyadi, 2012).

Menurut Krismiaji dan Aryani (2011), bahan baku dibedakan menjadi dua, yaitu:

1. Bahan baku langsung (direct material), adalah bahan yang menjadi bagian integral dari produk jadi dan secara fisik serta secara meyakinkan dapat ditelusur keberadaanya pada produk jadi.

2. Bahan baku tidak langsung (indirect material) adalah bahan yang tidak dapat ditelusur secara fisik keberadannya pada produk jadi.

Adapun jumlah persediaan bahan baku yang harus dipertahankan oleh perusahaan menurut Sunyoto (2013) akan sangat bergantung pada:

1. Waktu yang dibutuhkan sejak saat pemesanan sampai dengan bahan diterima (lead time).

Jika perusahaan ingin berproduksi secara lancar maka lead time harus dipertimbangkan dengan baik, mengingat ada tenggang waktu antara saat pemesanan dengan penerimaan barang, sehingga dengan adanya pengaturan yang baik maka jumlah persediaan yang ada akan selalu cukup untuk memenuhi kebutuhan produksi.

2. Jumlah pemakaian

Semakin banyak suatu bahan digunakan dalam proses produksi maka semakin besar jumlah persediaan bahan mentah tersebut yang dibutuhkan oleh perusahaan.

3. Jumlah investasi dalam persediaan

Jumlah investasi yang dibutuhkan dalam persediaan juga memegang peranan penting dalam menentukan tingkat persediaan. Dimana pemesanan bahan mentah secara periodik dalam jumlah yang cukup besar sudah dapat menjamin kelancaran proses produksi. Sebaliknya untuk bahan- 
bahan mentah yang berharga mahal, maka kantor lead time dan frekuensi pemakaian harus mendapat perhatian yang lebih besar karena jumlah modal yang akan diinvestasikan dalam persediaan yang mahal akan cukup besar.

4. Karakteristik fisik dari bahan mentah yang dibutuhkan

Karakteristik fisik bahan mentah seperti ukuran besar kecil, kondisi baik atau jelek. Untuk bahan mentah yang cepat rusak jangan dipesan dalam jumlah besar karena hal itu akan merugikan, walaupun dari segi harga dikatakan murah.

\section{Pengendalian Persediaan}

Herjanto (2008) mengatakan bahwa pengendaliaan persediaan adalah serangkaian kebijakan pengendalian untuk menentukan tingkat persediaan yang harus dijaga, kapan pesanan untuk menambah persediaan harus dilakukan dan berapa besar pesanan harus diadakan, jumlah atau tingkat persediaan yang dibutuhkan berbeda-beda untuk setiap perusahaan pabrik, tergantung volume produksinya, jenis perusahaan dan prosesnya. Menurut Assauri (2008), Pengendaliaan persediaan (inventory control) adalah suatu kegiatan yang ditujukan agar persediaan atau stock yang ada tidak akan mengalami kekurangan dan dapat dijaga tingkat yang optimal sehingga biaya persediaan dapat optimal.

\section{Tujuan Pengendaliaan Persediaan}

Menurut Assauri (2008), tujuan pengendalian persediaan dapat diartikan sebagai usaha untuk:

1. Menjaga jangan sampai perusahaan kehabisan persediaan yang mengakibatkan terhentinya kegiatan produksi.

2. Menjaga agar pembentukan persediaan oleh perusahaan tidak terlalu besar atau berlebihan, sehingga biaya-biaya yang timbul dari persediaan tidak terlalu besar.

3. Menjaga agar pembelian secara kecil-kecilan dapat dihindari karena ini akan berakibat biaya pesanan menjadi besar.

\section{Economic Order Quantity (EOQ)}

Menurut Margaretha (2011), Economic Order Quantity (EOQ) berarti jumlah unit barang/bahan yang harus dipesan setiap kali mengadakan pemesanan agar biaya-biaya yang berkaitan dengan pengadaan persediaan minimal, atau jumlah unit pembelian yang paling optimal. Sedangkan Heizer dan Render (2011) mendefinisikan kuantitas pesanan ekonomis (Economic Order Quantity) adalah salah satu teknik kontrol persediaan yang meminimalkan biaya total dari pemesanan dan penyimpanan.

\section{Persediaan Pengaman (Safety Stock)}

Untuk memesan suatu barang sampai barang itu datang diperlukan jangka waktu yang bisa bervariasi dari beberapa jam sampai beberapa bulan. Perbedaan waktu antara saat memesan sampai 
saat barang datang dikenal dengan istilah waktu tenggang (lead time). Waktu tenggang sangat dipengaruhi oleh ketersediaan dari barang itu sendiri dan jarak lokasi antara pembelian dan pemasok berada. Karena adanya waktu tenggang, perlu adanya persediaan yang dicadangkan untuk kebutuhan selama menunggu barang datang, yang disebut sebagai persediaan pengamanan (safety stock). Menurut Haming dan Nurnajamudin (2012), persediaan pengaman merupakan unit persediaan yang harus selalu ada dalam perusahaan untuk mengantisipasi fluktuasi permintaan dan menghindari terjadinya kehabisan stock. Sedangkan menurut Sunyoto (2013), persediaan pengaman (safety stock) adalah persediaan tambahan yang dimiliki untuk berjaga-jaga terhadap perubahan tingkat penjualan atau keterlambatan produksi atau pengiriman.

\section{Titik Pemesanan Ulang (Re Order Point)}

Menurut Riyanto (2010), Re Order Point adalah saat atau titik dimana harus diadakan pesanan lagi sedemikian rupa sehingga kedatangan atau penerimaan material yang dipesan itu adalah tepat pada waktu dimana persediaan di atas safety stock sama dengan nol. Margaretha (2011) mengemukakan bahwa Reorder Point ialah saat/titik dimana pemesanan harus dilakukan lagi untuk mengisi persediaan. Sedangkan menurut Fahmi (2014), Re Order Point adalah titik dimana suatu perusahaan atau intuisi bisnis harus memesan barang atau bahan guna menciptakan kondisi persediaan yang terus terkendali.

\section{METODE PENELITIAN}

\section{Ruang Lingkup dan Lokasi Penelitian}

Ruang lingkup penelitian ini berkonsentrasi pada mata kuliah Manajemen Operasional. Penelitian ini dilakukan pada PT. Aceh Rubber Industries Kabupaten Aceh Tamiang. Lokasi Perusahaan ini berada di jalan Medan-Banda Aceh Dusun Damai, Desa Paya Ketenggar Kecamatan Manyak Payed Kabupaten Aceh Tamiang. Adapun penelitian ini dilaksanakan pada bulan FebruariMei 2017.

\section{Jenis dan Sumber Data}

Jenis data yang digunakan dalam penelitian ini berupa :

1. Data Kualitatif

Data kualitatif adalah data yang berbentuk kalimat, kata atau gambar (Sugiyono, 2010). Data kualitatif pada penelitian ini berupa data karyawan, struktur organisasi dan teori-teori yang berhubungan dengan penelitian pada PT. Aceh Rubber Industries Kabupaten Aceh Tamiang.

2. Data Kuantitatif

Data Kuantiatif adalah data yang berbentuk angka (Sugiyono, 2010). Data kuantitatif pada penelitian ini berupa data persediaan serta biaya-biaya persediaan pada PT. Aceh Rubber Industries Kabupaten Aceh Tamiang. 
Sumber data pada penelitian ini dibagi menjadi dua sumber yaitu:

1. Data Primer merupakan sumber data yang langsung memberikan data kepada pengumpul data (Sugiyono, 2012). Dalam hal ini peneliti melakukan observasi dan bertanya langsung dengan sumber yang diamati yaitu pihak PT. Aceh Rubber Industries Kabupaten Aceh Tamiang.

2. Data sekunder yaitu sumber yang tidak langsung memberikan data kepada pengumpul data, misalnya lewat dokumen (Sugiyono, 2012). Dalam hal ini peneliti meminta data yang berhubungan dengan objek yang diteliti yaitu berupa data laporan persediaan bahan baku serta data biaya-biaya persediaan PT. Aceh Rubber Industries Kabupaten Aceh Tamiang.

\section{Metode Pengumpulan Data}

Metode yang digunakan dalam pengumpulan data pada penelitian ini dilakukan dengan cara sebagai berikut:

1. Penelitian Lapangan

a. Observasi teknik pengumpulan data dengan cara mengamati, melihat dan mengidentifikasi yang menjadi objek penelitian yaitu pada PT. Aceh Rubber Industries Kabupaten Aceh Tamiang.

b. Wawancara (interview) yaitu teknik pengumpulan data dimana mendatangi langsung atau bertemu dengan informan untuk mendapatkan informasi yang relevan dengan penelitian. Dalam hal ini wawancara dilakukan pada pimpinan dan staf bagian persediaan pada PT. Aceh Rubber Industries Kabupaten Aceh Tamiang.

c. Dokumentasi, yaitu teknik pengumpulan data yang dilakukan dengan cara mengumpulkan dan mengambil data, catatan atau dokumen perusahaan yang terkait dengan penelitian yaitu pada PT. Aceh Rubber Industries Kabupaten Aceh Tamiang.

2. Penelitian Kepustakaan yaitu pengumpulan data yang dilakukan melalui membaca buku teoritis, jurnal-jurnal peneliti terdahulu serta sarana media internet yang berkaitan dengan penelitian.

\section{Metode Analisis Data}

Metode analisis yang digunakan dalam penelitian ini adalah sebagai berikut :

1. Menentukan Economic Order Quantity (EOQ)

Untuk menentukan jumlah pesanan yang ekonomis (EOQ) dapat dihitung dengan rumus :

$\mathrm{EOQ}=\sqrt{\frac{2 . S . D}{H}}$

Keterangan :

EOQ / Q* = jumlah pemesanan (unit/pesanan)

$\mathrm{S}$ = biaya pemesanan (rupiah/pesanan)

$\mathrm{D}=$ jumlah kebutuhan barang (unit/tahun)

$\mathrm{H}=$ biaya penyimpanan (unit/tahun) 
2. Menentukan Total Biaya Persediaan

Rumus biaya pemesanan menurut Handoko (2012:339) adalah sebagai berikut :

Biaya pemesanan $=S \frac{\mathrm{D}}{\mathrm{Q}}$

Keterangan:

$\mathrm{D}=$ Permintaan barang persediaan, dalam unit pertahun

$\mathrm{Q}=$ Jumlah barang setiap dipesan

$\mathrm{S}=$ Biaya pemesanan untuk setiap kali pemesanan

Sedangkan biaya penyimpanan merupakan biaya yang harus ditanggung oleh perusahaan sehubungan dengan adanya bahan baku yang disimpan didalam perusahaan. Semakin banyak barang yang disimpan, maka akan semakin besar barang persediaan dan semakin besar pula biaya penyimpanannya.

Menurut Handoko (2012), rumus biaya penyimpanan adalah sebagai berikut:

Biaya penyimpanan $=H \frac{Q}{2}$

Keterangan:

$\mathrm{Q}=$ Jumlah barang setiap pesanan

$\mathrm{H}=$ Biaya penyimpanan per unit (satuan) per tahun

Rumus total biaya persediaan (TC) menurut Handoko (2012) adalah sebagai berikut:

$\mathbf{T C}=\mathbf{H} \frac{\mathbf{Q}}{2}+\mathbf{S} \frac{\mathrm{D}}{\mathbf{Q}}$

Keterangan:

$\mathrm{TC}=$ Total biaya persediaan

$\mathrm{D}=$ Permintaan tahunan barang persediaan dalam unit per tahun

$\mathrm{Q}=$ Jumlah barang setiap pesan

$\mathrm{S}$ = Biaya pemesanan untuk setiap kali melakukan pesanan

$\mathrm{H}$ = Biaya penyimpanan per unit tahun

\section{Menentukan Persediaan Pengamanan (Safety Stock)}

Rumus untuk menghitung Safety Stock menurut Assauri dalam Listyorini (2016) adalah sebagai berikut:

$S S=Z . d . L$

Keterangan:

SS = Safety Stock

$\mathrm{Z}=$ Service Level

$\mathrm{d}=$ Rata-rata pemakaian

$\mathrm{L}=$ Lead time 


\section{Menentukan Titik Pemesanan Kembali (Re Order Point)}

Rumus untuk menentukan Reorder Point menurut Sudana (2011) adalah sebagai berikut:

ROP $=$ Lt $\times$ Q

Keterangan :

$\mathrm{ROP}=$ Reoder point

$\mathrm{Lt}=$ Lead time

$\mathrm{Q}=$ Pemakaian rata-rata (per hari, per minggu, atau per bulan).

\section{HASIL DAN PEMBAHASAN}

\section{Analisis Pengendalian Bahan Baku Dengan Kebijakan PT. Aceh Rubber Industries}

Dalam menjalankan kegiatan produksinya PT. Aceh Rubber Industries berproduksi berdasarkan persediaan bahan baku yang ada di gudang. Bahan baku yang diterima dari para agen dan petani berapapun jumlahnya tetap diterima oleh perusahaan. Hal tersebut dilakukan agar Perusahaan tidak kekurangan bahan baku saat berproduksi dan perusahaan akan tetap berproduksi untuk memenuhi permintaan konsumen. Akan tetapi perusahaan ini belum memiliki metode dalam hal pengendalian terhadap persediaan bahan baku, karena PT. Aceh Rubber Industries beranggapan bahwa bahan baku tersebut selalu tersedia dan perusahaan tidak akan mengalami kekurangan pasokan bahan baku karena selalu memiliki persediaan, tetapi perusahaan tidak memperhatikan biaya yang akan ditimbulkan sehubungan dengan persediaan bahan baku tersebut.

Dalam penelitian ini akan dibahas mengenai metode pengendalian persediaan bahan baku yang optimal yaitu metode Economic Order Quantity (EOQ). Penggunaan metode Economic Order Quantity (EOQ) ini bertujuan untuk mengetahui jumlah persediaan yang harus dipesan dengan biaya yang minimal atau tingkat pembelian bahan baku yang optimal pada PT. Aceh Rubber Industries Kabupaten Aceh Tamiang pada tahun 2016.

\section{Kebutuhan Bahan Baku}

Kebutuhan bahan baku PT. Aceh Rubber Industries pada tahun 2016 sebanyak 5.454.266 kilogram. Frekuensi pembelian selama tahun 2016 sebanyak 48 kali, karena setiap 1 minggu sekali PT. Aceh Rubber Industries melakukan pembelian bahan baku.

Jadi jumlah pembelian rata-rata bahan baku selama setahun yang di lakukan PT. Aceh Rubber Industries adalah sebagai berikut:

Jumlah kebutuhan bahan baku $\quad=\frac{\text { kebutuhan bahan baku }}{\text { frekuensi pemesanan }}$

Di bulatkan menjadi $\quad=113.631 \mathrm{~kg}$.

\section{Biaya Pemesanan}

Biaya pemesanan merupakan biaya yang langsung terkait dengan kegiatan pemesanan bahan 
baku yang dilakukan perusahaan. Komponen biaya pemesanan bahan baku pada PT. Aceh Rubber Industries terdiri dari biaya administrasi dan biaya telepon.

1. Biaya administrasi pada PT. Aceh Rubber Industries sehubungan pembelian bahan baku pada tahun 2016 adalah sebesar Rp 2.500.000.

2. Biaya telepon yang dikeluarkan oleh PT. Aceh Rubber Industries yang digunakan untuk komunikasi dalam rangka pemesanan bahan baku pada tahun 2016 adalah sebesar Rp 1.200.000.

Tabel 1. Biaya Pemesanan Bahan Baku

\begin{tabular}{clc}
\hline No. & \multicolumn{1}{c}{ Biaya } & Rincian \\
\hline 1 & Biaya admnistrasi & $\mathrm{Rp} 2.500 .000$ \\
\hline 2 & Biaya telepon & $\mathrm{Rp} 1.200 .000$ \\
\hline & Total & $\mathrm{Rp} \mathrm{3.700.000}$ \\
\hline
\end{tabular}

Sumber : PT. Aceh Rubber Industries (data diolah 2016).

Perhitungan biaya pemesanan bahan baku adalah sebagai berikut:

Biaya pemesanan $=\frac{\text { total biaya pemesanan }}{\text { frekuensi pemesanan }}$

$$
=\frac{\operatorname{Rp} 3.700 .000}{48}=\operatorname{Rp} 77.083,3333
$$

Biaya ini dibulatkan menjadi $\quad=\operatorname{Rp} 77.083$

\section{Biaya Penyimpanan}

Biaya penyimpanan merupakan biaya yang harus ditanggung oleh PT. Aceh Rubber Industries sehubungan dengan adanya bahan baku yang disimpan didalam perusahaan. Biaya yang harus dikeluarkan oleh perusahaan berupa biaya perawatan gudang dan biaya listrik.

1. Biaya perawatan gudang pada tahun 2016 adalah sebesar Rp 25.680 .000

2. Biaya listrik untuk penyimpanan bahan baku pada tahun 2016 sebesar Rp14.400.000.

Tabel 2. Biaya Penyimpanan Bahan Baku

\begin{tabular}{clc}
\hline No. & \multicolumn{1}{c}{ Biaya } & Rincian \\
\hline 1 & Biaya perawatan gudang & Rp 25.680.000 \\
\hline 2 & Biaya listrik & Rp 14.400 .000 \\
\hline & Total & Rp 40.080.000 \\
\hline
\end{tabular}

Sumber : PT. Aceh Rubber Industries (data diolah 2016).

Jadi biaya penyimpanan bahan baku adalah

Total biaya penyimpanan sebesar $\mathrm{Rp} 40.080 .000$

Jumlah kebutuhan bahan baku sebanyak $5.454 .266 \mathrm{~kg}$. 
Biaya penyimpanan $\quad=\frac{\text { total biaya penyimpanan }}{\text { jumlah kebutuhan bahan baku }}$

$$
=\frac{\mathrm{Rp} 40.080 .000}{5.454 .266 \mathrm{~kg}}=\operatorname{Rp} 7,348 \text { per kilogram }
$$

Biaya penyimpanan ini di bulatkan menjadi Rp 7 per kilogram karet.

\section{Total Biaya Persediaan (TIC)}

Total biaya persediaan dapat dihitung dengan rumus:

$\mathrm{TIC}=\mathrm{H} \frac{Q}{2}+\mathrm{S}_{Q}^{D}$

Jadi total biaya persediaan bahan baku adalah sebagai berikut:

$$
\begin{aligned}
\text { TIC } & =\mathrm{H} \frac{Q}{2}+\mathrm{S} \frac{D}{Q} \\
\text { TIC } & =7\left(\frac{113.631}{2}\right)+77.083\left(\frac{5.454 .266}{113.631}\right) \\
& =397.708,5+3.699 .969,07 \\
& =\operatorname{Rp} 4.097 .677,57
\end{aligned}
$$

Dibulatkan menjadi $=$ Rp 4.097.678

\section{Analisis Kebutuhan Bahan Baku dengan Metode EOQ}

Perhitungan pengendalian persediaan bahan baku dengan menggunakan metode EOQ bertujuan untuk mengetahui tingkat pembelian bahan baku yang optimal pada PT. Aceh Rubber Industries Kabupaten Aceh Tamiang yang dapat meminimumkan biaya persediaan, dengan cara:

\section{Perhitungan Jumlah Pembelian Bahan Baku yang Optimal}

$\mathrm{EOQ} / \mathrm{Q}^{*}=\sqrt{\frac{2 . S . D}{H}}$

Diketahui:

Kebutuhan karet (D) sebesar 5.454.266 kg

Biaya penyimpanan (H) Rp 7 per kilogram

Biaya pemesanan (S) Rp 77.083

$$
\begin{aligned}
\mathrm{EOQ} / \mathrm{Q}^{*} & =\sqrt{\frac{2 . S . D}{H}} \\
& =\sqrt{\frac{2 .(77.083) \cdot(5.454 .266)}{7}} \\
& =\sqrt{\frac{2(420.431 .186 .078)}{7}} \\
& =\sqrt{120.123 .196 .022,2857} \\
& =346.587,93
\end{aligned}
$$


Dibulatkan menjadi $=346.588 \mathrm{~kg}$.

\section{Perhitungan Frekuensi Pembelian Optimal}

$\mathrm{F}^{*}=\frac{D}{Q *}$

Diketahui:

$\mathrm{D}=5.454 .266 \mathrm{~kg}$

$\mathrm{Q}^{*}=346.588 \mathrm{~kg}$

$\mathrm{F}^{*}=\frac{D}{Q *}$

$$
=\frac{5.454 .266}{346.588}=15,73 \mathrm{kali}
$$

Dibulatkan menjadi 16 kali

\section{Total Biaya Persediaan Bahan Baku Optimal}

$\mathrm{TIC}=\mathrm{H} \frac{\mathrm{Q}}{2}+\mathrm{S} \frac{\mathrm{D}}{\mathrm{Q}}$

Diketahui:

$\mathrm{D}=5.454 .266 \mathrm{~kg}$

$\mathrm{Q}=346.588 \mathrm{~kg}$

$\mathrm{S}=\mathrm{Rp} 77.083$

$\mathrm{H}=\mathrm{Rp} 7$ per $\mathrm{kg}$

$\mathrm{TIC}=\mathrm{H} \frac{\mathrm{Q}}{2}+\mathrm{S} \frac{\mathrm{D}}{\mathrm{Q}}$

$\mathrm{TIC}=7 \frac{346.588}{2}+77.083 \frac{5.454 .266}{346.488}$

$=1.213 .058+1.213 .408$

$=\operatorname{Rp} 2.426 .466$

\section{Perhitungan Persediaan Pengaman (Safety Stock)}

Untuk menentukan jumlah persediaan pengaman (Safety Stock)dapat dihitung dengan menggunakan rumus:

$$
S S=Z . d . l
$$

Dengan pemakaian asumsi bahwa PT. Aceh Rubber Industries menerapkan persediaan untuk mampu memenuhi permintaan konsumen (service level) yaitu sebesar 95\%, sehingga dapat diperoleh $\mathrm{Z}$ dengan tabel normal sebesar 1,64. Menghitung jumlah rata-rata pemakaian bahan baku per hari adalah sebagai berikut:

$$
\begin{aligned}
& \mathrm{d}=\frac{\mathrm{D}}{\text { jumlah hari kerja setahun }} \\
& \mathrm{d}=\frac{5.454 .266}{312}=17.481,6
\end{aligned}
$$


dibulatkan menjadi $17.482 \mathrm{~kg}$.

Maka persediaan pengaman dapat dihitung sebagai berikut:

$S S=Z \cdot d . l$

Diketahui:

Service level $=95 \%(\mathrm{Z}=1,64)$

$d=17.482 \mathrm{~kg}$

$l=7$ hari

$$
\begin{aligned}
\mathrm{SS} & =1,64 \times 17.482 \times 7 \\
& =200.693,36 \mathrm{~kg} .
\end{aligned}
$$

Dibulatkan menjadi $=200.693 \mathrm{~kg}$.

\section{Menentukan Besarnya Titik Pemesanan Kembali (Re Order Point)}

$\mathrm{ROP}=(\mathrm{d} . \mathrm{L})+\mathrm{SS}$

Diketahui:

$\mathrm{Lt}=7$ hari

Jumlah hari kerja dalam 1 tahun adalah 312 hari

Jumlah pemakaian karet adalah $5.454 .266 \mathrm{~kg}$

Maka:

Rata-rata pemakaian bahan baku adalah:

$\frac{5.454 .266}{312}=17.481,62$ di bulatkan menjadi 17.482

$$
\begin{aligned}
\text { ROP } & =(\text { d.L })+S S \\
& =(17.482 \times 7)+200.693 \\
& =323.067 \mathrm{~kg}
\end{aligned}
$$

Berikut ini perbandingan pengendalian persediaan bahan baku antara kebijakan perusahaan dengan metode EOQ dapat dilihat pada tabel 3 di bawah ini:

Tabel 3. Perbandingan Pengendalian Persediaan Bahan Baku Antara

Kebijakan Perusahaan dengan Metode EOQ

\begin{tabular}{lrr}
\hline \multicolumn{1}{c}{ Keterangan } & $\begin{array}{c}\text { Kebijakan } \\
\text { perusahaan }\end{array}$ & \multicolumn{1}{c}{ Metode EOQ } \\
\hline Kuantitas pembelian & $113.631 \mathrm{~kg}$ & $346.588 \mathrm{~kg}$ \\
\hline Frekuensi pembelian & $48 \mathrm{kali}$ & $16 \mathrm{kali}$ \\
\hline Total biaya persediaan & $\mathrm{Rp} 4.097 .678$ & $\mathrm{Rp} \mathrm{2.426.466}$ \\
\hline Persediaan pengaman & - & $200.693 \mathrm{~kg}$ \\
\hline Titik pemesanan ulang & - & $323.067 \mathrm{~kg}$ \\
\hline \multicolumn{2}{l}{ Sumber : hasil penelitian (data diolah tahun 2016). }
\end{tabular}


Berdasarkan tabel 3 dapat diketahui perbedaan persediaan bahan baku antara kebijakan perusahaan dengan metode EOQ. Kuantitas pembelian bahan baku yang ekonomis berdasarkan kebijakan perusahaan adalah sebesar $113.631 \mathrm{~kg}$, dengan frekuensi pembelian sebanyak 48 kali dalam setahun. Sedangkan kuantitas pembelian yang ekonomis menurut metode EOQ adalah sebesar 346.588 $\mathrm{kg}$, dengan frekuensi pembelian sebanyak 16 kali dalam setahun. Total biaya persediaan menurut kebijakan perusahaan adalah sebesar Rp 4.097.678, sedangkan menurut metode EOQ adalah sebesar Rp 2.426.466, dalam hal ini dengan menggunakan metode EOQ perusahaan dapat menghemat biaya persediaan sebesar Rp 1.671.212. Sementara itu untuk persediaan pengaman dan titik pemesanan kembali menurut kebijakan perusahaan tidak ada, hal ini menyebabkan perusahaan bisa saja tidak berproduksi karena kehabisan bahan baku sebelum melakukan pemesanan kembali atau bahan baku yang dipesan tersebut belum sampai ke perusahaan, sedangkan menurut perhitungan metode EOQ besarnya persediaan pengaman adalah sebanyak $200.693 \mathrm{~kg}$ dan titik pemesanan ulang sebesar $323.067 \mathrm{~kg}$. Sehingga berdasarkan angka tersebut maka perusahaan akan tetap berproduksi karena perusahaan masih mempunyai persediaan bahan baku cadangan yang akan digunakan selama masa tunggu pemesanan bahan baku tersebut belum sampai ke perusahaan.

Hasil analisis di atas diketahui bahwa berdasarkan metode EOQ dalam hal pengendalian persediaan bahan baku lebih efektif dan efisien jika dibandingkan dengan kebijakan yang selama ini digunakan oleh perusahaan. Dalam hal ini dengan menerapkan metode EOQ perusahaan akan lebih menghemat biaya-biaya yang berhubungan dengan persediaan, selain itu dengan menerapkan metode EOQ perusahaan akan mengetahui kapan pembelian bahan baku kembali harus dilakukan dan dapat mengendalikan seberapa besar tingkat pembelian bahan baku tersebut, sehingga perusahaan akan terus berproduksi tanpa takut kehabisan bahan baku dan perusahaan bisa memenuhi permintaan konsumen setiap saat serta akan terhindar dari kerugian. Berdasarkan analisis diatas dapat disimpulkan bahwa pengendalian persediaan bahan baku yang dilakukan oleh PT. Aceh Rubber Industries belum efektif.

Hasil penelitian ini didukung oleh penelitian yang dilakukan Robyanto, dkk (2013), bahwa dengan menggunakan analisis EOQ perusahaan dapat lebih mengefisienkan biaya persediaan bahan baku sehingga perusahaan dapat mengalokasikan anggaran persediaan yang berlebihan untuk keperluan lainnya yang lebih menguntungkan. Hasil penelitian ini juga sesuai dengan pendapat yang disampaikan oleh Margaretha (2011:40) Economic Order Quantity (EOQ) adalah jumlah unit barang/bahan yang harus dipesan setiap kali mengadakan pemesanan agar biaya-biaya yang berkaitan dengan pengadaan persediaan minimal, atau jumlah unit pembelian yang optimal.

\section{KESIMPULAN DAN SARAN}

\section{Kesimpulan}

Hasil penelitian diketahui bahwa jumlah pembelian bahan baku optimal menurut kebijakan perusahaan adalah sebanyak $113.631 \mathrm{~kg}$, sedangkan menurut metode EOQ adalah sebanyak 346.588 kg. Frekuensi pembelian karet optimal menurut kebijakan perusahaan adalah 48 kali dalam setahun, 
sedangkan berdasarkan metode EOQ adalah sebanyak 16 kali. Total biaya persediaan menurut kebijakan perusahaan adalah sebesar Rp 4.097.678, sedangkan menurut metode EOQ adalah sebesar Rp 2.426.466. Sehingga dengan menggunakan metode EOQ perusahaan dapat menghemat biaya persediaan sebesar Rp 1.671.212. Persediaan pengaman menurut kebijakan perusahaan tidak ada, sedangkan menurut perhitungan metode OEQ adalah sebanyak $200.693 \mathrm{~kg}$. Titik pemesanan kembali menurut kebijakan perusahaan tidak ada, sedangkan menurut perhitungan metode EOQ adalah sebanyak $323.067 \mathrm{~kg}$.

\section{Saran}

PT. Aceh Rubber Industries sebaiknya menerapkan metode Economic Order Quantity (EOQ) dalam melakukan pengendalian terhadap persediaan bahan baku karena dapat menghemat biaya-biaya yang berhubungan dengan persediaan. PT. Aceh Rubber Industries juga harus memperhitungkan besarnya persediaan pengaman (Safety Stock) dan pemesanan kembali (Re Order Point) untuk menghindari risiko kehabisan maupun kelebihan bahan baku, hal tersebut dimaksudkan agar perusahaan akan tetap berproduksi apabila bahan baku yang dipesan lama tiba di pabrik.

\section{REFERENSI}

Assauri, Sofyan. 2008, Manajemen Produksi dan Operasi. Jakarta: Lembaga Penerbit Fakultas Ekonomi UI.

Deitiana, Tita. 2011. Manajemen Operasional Strategi dan Analisa Service dan Manufaktur. Jakarta: Mitra Wacana Media.

Fahmi, Irham. 2014. Manajemen Produksi dan Operasi. Bandung: Alfabeta.

Haming, Murfudin dan Mahfud Nurnajamudin. 2012. Manajemen Produksi Modern Operasi Manufaktur dan Jasa. Jakarta: Mitra Wacana Media.

Handoko, T. Hani. 2012. Dasar-dasar Manajemen Produksi dan Operasi. Yogyakarta: BPFE.

Heizer, Jay dan Barry Render. 2011, Manajemen Operasi Edisi 9, Jakarta : Salemba Empat. . 2015. Manajemen Operasi-Manajemen Keberlangsungan dan

Rantai Pasokan. Jakarta: Salemba Empat.

Herjanto, Eddy. 2008. Manajemen Operasi. Edisi Ketiga. Jakarta: PT. Grasindo.

Ishak, Aulia. 2010. Manajemen Operasi. Yogyakarta: Graha Ilmu.

Krismiaji dan Aryani Y. A. 2011. Akuntasi Manajemen. Edisi Kedua. Yogyakarta: Sekolah Tinggi Ilmu Manajemen YKPN.

Margaretha, Farah. 2011. Manajemen Keuangan Untuk Manajer Non Keuangan. Jakarta: Erlangga.

Mulyadi. 2012, Akuntansi Biaya. Yogyakarta: STIIM YKPN.

Pardede, Pontas M. 2005. Manajemen Operasi dan Produksi Teori, Model dan Kebijakan, Yogyakarta: Penerbit ANDI.

Rakian, Atdri. 2015. Analisis Pengendalian Persediaan Bahan Baku Tepung Terigu Menggunakan Metode EOQ pada Pabrik Mie Musbar Pekan Baru. JOM FEKON. Vol.2. No. 1. Hal. 1-15.

Rasyid, Nirwan, 2015. Analisis Perencanaan Persediaan Kacang Kedelai pada Unit Usaha Primer Koperasi Produsen Tempe Tahu Indonesia di Palembang. Jurnal Manajemen dan Bisnis Sriwijaya. Vol. 13. No. 1. Hal. 21-38.

Riyanto, Bambang. 2010. Dasar-dasar Pembelanjaan Perusahaan. Yogyakarta: BPFE.

Robyanto, Chairul Bahtiar, dkk. 2013. Analisis Persediaan Bahan Baku Tebu pada Pabrik Gula Pandji PT. Perkebunan Nusantara XI (Persero) Situbondo, Jawa Timur. E-Jurnal Agribisnis dan Agrowisata. Vol. 2. No. 1. Hal. 23-31.

Sudana, I Mad. 2011. Manajemen Keuangan Perusahaan Teori dan Praktik. Jakarta: Erlangga. 
Sugiyono. 2010. Statistika Untuk Penelitian. Bandung: Alfabeta.

2012. Metode Penelitian Bisnis. Bandung: Alfabeta.

Sunyoto, Danang. 2013. Dasar-dasar Manajemen Keuangan Perusahaan. Yogyakarta: CAPS.

Tuerah, Michel Chandra. 2014. Analisis Pengendalian Persediaan Bahan Baku Ikan Tuna Pada CV. Golden KK. Jurnal EMBA. Vol. 2. No. 4. Hal. 524-536.

Wahyudi, Rudy. 2015. Analisis Pengendalian Persediaan Barang Berdasarkan Metode EOQ di Toko Era Baru Samarinda. eJournal Ilmu Administrasi Bisnis. Vol. 2. No. 1. Hal. 162-173. 